\title{
Subject Data Event
}

National Cancer Institute

\section{Source}

National Cancer Institute. Subject Data Event. NCI Thesaurus. Code C142717.

Information produced, compiled, or examined during a visit with a clinical trial subject. 